\title{
Performance of Fusarium oxysporum EKT01/02 isolate in cyanide biodegradation system
}

\author{
Enoch Akinbiyi Akinpelu ${ }^{\dagger}$, Adewole Tomiwa Adetunji, Seteno Karabo Obed Ntwampe, \\ Felix Nchu, Lukhanyo Mekuto
}

Bioresource Engineering Research Group (BioERG), Cape Peninsula University of Technology, Keizersgracht and Tennant Street, Zonnebloem, P.O. Box 652, Cape Town, 8000, South Africa

\begin{abstract}
This study reports a cyanide resistant and/or tolerant fungus, isolated from the rhizosphere of Zea mays contaminated with cyanide-based pesticides. The isolate was characterised using molecular biology. The effect of free cyanide and heavy metals on the growth of isolate in a synthetic gold mine wastewater was examined. The molecular analyses identified the isolate as Fusarium oxysporum EKT01/02 (KU985430/KU985431). The isolate had a free cyanide degradation efficiency of $77.6 \%$. The results indicated greater growth impairment in culture containing Arsenic (optical density 1.28 and 1.458) and cyanide (optical density 1.315 and 1.385). Higher growth was observed in all cultures supplemented with extracellular polymeric substance. This study showed that the isolate possesses wide substrate utilisation mechanism that could be deployed in environmental engineering applications.
\end{abstract}

Keywords: Biodegradation, Cyanide, Fusarium oxysporum, ITS, TEF 1- $\alpha$

\section{Introduction}

The utilisation of cyanide in the minerals industry is vast despite its toxicity due to its affinity for metals. Therefore, free cyanide $(\mathrm{CN})$ and metal complex cyanides are released into the environment due to the insufficient treatment of wastewater generated from such metal recovery operations. The danger to humans and the ecological system is thus prominent; as such, there are several reports that indicate the impact of pollutants such as $\mathrm{CN}^{-}$and their contribution to the global burden of diseases [1, 2]. Several processes have been used to degrade cyanide namely; photodecomposition, volatilisation, oxidation and biodegradation [3]. Chemical methods such as alkaline chlorination and hydrogen peroxide oxidation are commonly used for the treatment of cyanidecontaminated wastewater owing to their suitability for achieving low levels of $\mathrm{CN}^{-}$and weak acid dissociable (CN-WAD) cyanides as by-products. However, these methods have high operational costs, with unfavourable by-products, which further deteriorates the environment [1].

Biological degradation processes have increasingly gained popu- larity due to their cost effectiveness, robustness and environmental benignity, with a great deal of research being conducted in this area [4]. Besides the biological cyanide degradation system at the Homestake Mine, (Dakota USA), a biological process named the Activated Sludge Tailings Effluent Remediation (ASTER ${ }^{\mathrm{TM}}$ ) technology, is being used for the safe handling of effluent containing $\mathrm{CN}^{-}$and thiocyanate $\left(\mathrm{SCN}^{-}\right)$in South Africa $[5,6]$. The processes have been widely reported to be dominated by bacterial and fungal organisms, which facilitate the biodegradation process. Fungal species such as Aspergillus sp. and Fusarium sp. and bacterial species such as Bacillus sp. and Pseudomonas sp., amongst others, have been found to utilise cyanide as a nitrogen source and/or carbon source, which generally results in the production of ammonium-nitrogen $\left(\mathrm{NH}_{4}^{+}-\mathrm{N}\right)$ [7-10].

Here, we report the potential of Fusarium oxysporum (F. oxysporum) in biodegradation of cyanide containing wastewater. Extracellular polymeric substance (EPS) produced by the isolate was used to support the growth of the isolate in gold mine wastewater containing cyanide and heavy metals. Impact of cyanide on the architecture of the isolate and the suitability of the isolate for heavy metals and free cyanide biodegradation was investigated.

Received October 23, 2017 Accepted February 6, 2018

${ }^{\dagger}$ Corresponding author

Email: biyipelu@gmail.com

Tel: +27-21-400-9097 Fax: +27-21-460-3282

ORCID: 0000-0003-3448-7868

Copyright (C) 2018 Korean Society of Environmental Engineers 


\section{Experimental}

\subsection{Fungal Isolation and Identification}

Fungi were isolated from the rhizosphere of Zea mays (Z. mays) contaminated with $\mathrm{CN}^{-}$-based pesticides. The rhizosphere of $Z$. mays was sprinkled into a Potato Dextrose Agar (PDA) plate and maintained at room temperature for between five and seven days depending on isolate's growth. The isolates were sub-cultured repeatedly on PDA plates in order to obtain pure colonies, subsequent to incubation for five days at $25 \pm 1{ }^{\circ} \mathrm{C}$, alternating exposure to light and darkness at $12 \mathrm{~h}$ interval for optimum growth [11]. The fungus isolate was identified both morphologically and by structural ribosomal deoxyribonucleic acid (rDNA) sequencing analysis. The genomic DNA was extracted using a PowerBiofilm DNA kit (MOBIO Laboratories, Inc., CA-USA) according to the manufacturer's instructions. The Polymerase Chain Reaction (PCR) amplification and sequencing was done using the universal primers ITS1/ITS4 (ITS1: ITS 'TCCGTAGGTGAACCTGCGG' and ITS4: ITS 'TCCTCCGCTTATTGATATGC') including EF1F/EF1R (EF1F: 'ATGGGTAAGGARGACAAGAC' and EF1R: 'GGARGTACCAGTS ATCATGTT'), as described earlier [12]. The QIAquick PCR purification kit (Qiagen, Hilden, Germany) was used to purify the amplicons. EKT01 represents the amplicons from TEF $1-\alpha$ gene while EKT02 denotes those of ITS gene. Sequences were run on a CLC Main Workbench 7 and blasted against the National Centre for Biotechnology Information (NCBI, www.ncbi.nlm.nih.gov) database. Alignment of 16 nucleotide sequences from the NCBI database and obtained sequences was done using the MAFFT online server (MAFFT version 7, http://mafft.cbrc.jp/alignment/server/). The aligned sequences were imported into the Molecular Evolutionary Genetics Analysis (MEGA) software version 6 [13], which was used for sequence analyses. The evolutionary history was done for the individual dataset obtained. The neighbour joining (NJ) method based on the Kimura 2-parameter model with 1,000 bootstrapped data sets was used [14]. All trees are drawn to scale, with positions $<95 \%$ site coverage eliminated.

\subsection{Extraction of Extracellular Polymeric Substance (EPS) from the Isolate}

The isolate was incubated in two different media: initially in nutrient broth and subsequently in gold mine wastewater containing $\mathrm{CN}^{-}$and heavy metals as shown in [15] with glucose as a carbon source for $48 \mathrm{~h}$ at $140 \mathrm{rpm}, 28^{\circ} \mathrm{C}$ and $\mathrm{pH}$ of 10 . After incubation, the culture was centrifuged at $10,000 \mathrm{rpm}$ for $10 \mathrm{~min}$ at $4^{\circ} \mathrm{C}$ in an Avanti ${ }^{\circledR}$ J-E centrifuge (Beckman Coulter, Inc., USA.). To the recovered supernatant, cold ethanol (96\% v/v, Merck, USA) at $4^{\circ} \mathrm{C}$ was added using a ratio of $1: 2$, i.e. supernatant: ethanol, and incubated overnight at $4^{\circ} \mathrm{C}$. The mixture was swirled and centrifuged at 10,000 rpm for $10 \mathrm{~min}$ at $4^{\circ} \mathrm{C}$. The EPS was rinsed twice in sterile distilled water (SDW) and dialysed in SDW overnight at $4^{\circ} \mathrm{C}$. The recovered EPS was lyophilised using Duran ${ }^{\circledR}$ desiccator.

\subsection{Cyanide Removal and Isolate Growth Assay}

The isolate was inoculated into two sets of reactors $(250 \mathrm{~mL}$ Erlenmeyer flasks) containing nutrient broth in a rotary shaker
(ZHICHENG ${ }^{\circledR}$ model ZHWY-200D, Shanghai, China) at $25^{\circ} \mathrm{C}, \mathrm{pH}$ of 10 and $140 \mathrm{rpm}$. After $24 \mathrm{~h}, \mathrm{CN}^{-}(\mathrm{KCN})$ was added to one of the reactors to make $100 \mathrm{mg} \mathrm{CN}^{-} / \mathrm{L}$ while the other set was free of $\mathrm{CN}^{-}$. The uninoculated reactor served as control. Samples (2 mL) were periodically withdrawn from the reactor and analysed for free cyanide biodegraded, residual ammonium-nitrogen and nitrate-nitrogen using Merck ${ }^{\circledR}$ cyanide $\left(\mathrm{CN}^{-}\right)$(09701), ammonium $\left(\mathrm{NH}_{4}{ }^{+}-\mathrm{N}\right)(00683)$ and nitrate $\left(\mathrm{NO}_{3}-\mathrm{N}\right)(14773)$ test kits respectively, in a NOVA 60 spectroquant. The procedures were in triplicate. Mass balance Eq. (1) and (2) were used to estimate free cyanide biodegraded, taking into account free cyanide volatilised.

$$
\begin{gathered}
C N_{B}=C N_{I}^{-}-C N_{R}^{-}-C N_{V} \\
C N_{V}=C N_{I}^{-}-C N_{F C}
\end{gathered}
$$

Where $C N_{B}$ is the free cyanide biodegraded; $C N_{I}^{-}$is the initial free cyanide in the media; $C N_{R}$ is the residual free cyanide after incubation period; $C N_{V}^{-}$is the free cyanide volatilised during culture incubation; $C N_{F C}$ is the final free cyanide in the control media. All measurements are in mg CN/L. The free cyanide removal efficiency (biodegradation efficiency) was determined using Eq. (3)

$$
\text { Biodegradation Efficiency }=\frac{C N_{B}^{-}}{C N_{F C}^{-}} \times 100
$$

After $120 \mathrm{~h}$, biofilm were harvested and visualized on a scanning electron microscopy (SEM: FEI Nova NanoSEM 230) with a field emission gun using the method described in Huddy et al (2015). Furthermore, heavy metal salts of $\mathrm{CuSO}_{4}, \mathrm{Na}_{2} \mathrm{HAsO}_{4}, \mathrm{PbBr}_{2}$, $\mathrm{Fe}_{2}\left(\mathrm{SO}_{4}\right)_{3}, \mathrm{ZnSO}_{4}$, and $\mathrm{CN}^{-}$in the form of KCN (Merck, USA), each at $1 \mathrm{mM}$ which was higher than effluent concentration reported by Acheampong (2013), were prepared in two sets of $50 \mathrm{~mL}$ nutrient broth, and inoculated with a loopful of the isolate and incubated at $28^{\circ} \mathrm{C}$ for $24 \mathrm{~h}$. Nutrient broth containing the isolate without $\mathrm{CN}^{-}$and heavy metal served as a control. Then, $1 \mathrm{mg}$ of the isolate's EPS was added to a set of inoculated nutrient broth and further incubated at $28^{\circ} \mathrm{C}$ overnight. The microbial growth was observed in a microplate reader; SpectraMax ${ }^{\circledR}$ M2 (Molecular Devices, California, USA) based on optical density at a wavelength of 300 $\mathrm{nm}$. All treatments were in triplicate.

\section{Results and Discussion}

The consensus nucleotide sequence amplicons of 703 base pair (bp) and $465 \mathrm{bp}$ were obtained for TEF 1- $\alpha$ and ITS genes from the isolate respectively. The sequences were deposited in NCBI database and assigned the following accession numbers: KU985430 for EKT01 and KU985431 for EKT02. The phylogenetic trees for individual sequences showed that the isolates belong to Fusarium sp. with bootstrap support for both ITS genes and TEF 1- $\alpha$ gene. EKT01 and EKT02 are most closely related to $F$. oxysporum isolate FUS1 and $F$. oxysporum strain SK 1649, respectively. The tree with the highest Log Likelihood is shown in Fig. 1 for each dataset. 


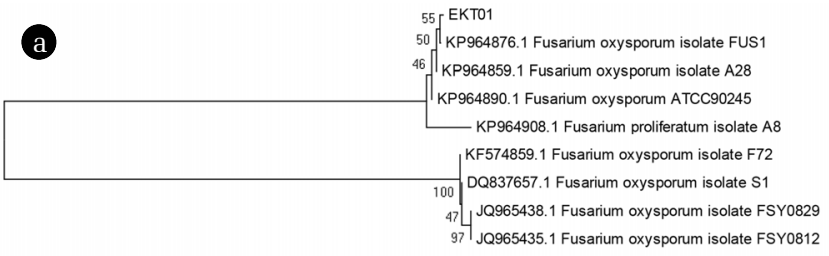

0.1

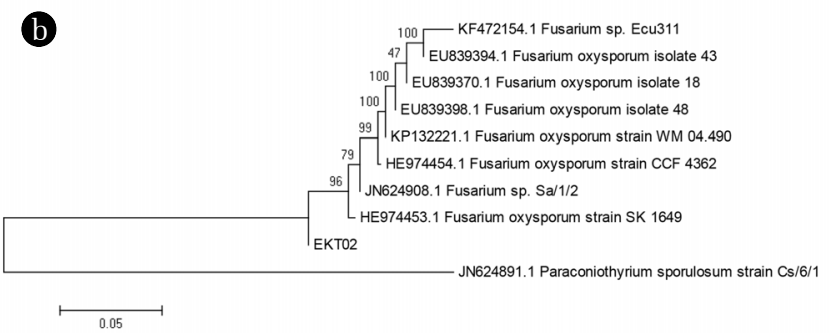

Fig. 1. Neighbour joining trees of (a) TEF 1-a genes and (b) ITS genes.

Previous reports on $F$. oxysporum f. sp. cubense showed that molecular genetic techniques could be used to determine a phylogenetic relationship [16]. The tree analysis of TEF 1- $\alpha$ was very similar to that of Taylor et al. (2016) and Bogale et al. [17]. The EPS recovered from isolate incubated on nutrient broth was miniscule (2 mg) compared with $40 \mathrm{mg}$ from cultures supplemented with wastewater containing $\mathrm{CN}^{\top}$ and heavy metals. This suggests that the EPS production system was a consequence of adaptation to the toxic environment which facilitated the isolate's ability to sustain its metabolic activity. The growth of the isolate was impaired in cultures supplemented with heavy metals, with the exception of $\mathrm{Fe}^{3+}$ cultures which showed to be highly tolerant of the contaminant at $1 \mathrm{mM}$. Arsenic (As) and $\mathrm{CN}^{-}$showed a greater inhibitory effect on the microbial growth of the isolate both with and without EPS. The supplementation of the EPS improved the growth of the isolate, see Fig. 2(a).

This indicated the ability of the isolate to protect itself against variations in toxicant concentration, an admirable trait suited for mining wastewater bioremediation. The inhibitory effect of As and $\mathrm{CN}^{-}$may be attributed to their tendencies to impede ATP production thereby disrupting oxidative phosphorylation [18].

Furthermore, the isolate showed degradation efficiency of $77.6 \%$ within five days from an initial free cyanide concentration of 100 mg CN/L (see Fig. 2(b)). The free cyanide loss owing to volatilisation was less than $10 \%$ with residual ammonium-nitrogen and nitrate-nitrogen being $30.1 \mathrm{mg} / \mathrm{L}$ and $0.2 \mathrm{mg} / \mathrm{L}$, respectively. The accumulation of ammonium suggested a hydrolytic mechanism utilisation in the cyanide biodegradation process by the isolate $[19,20]$. The micrographs showed that the microbial biomass is embedded in EPS which plays a major role in the structural integrity of the biofilm formed; hence, its resistance to toxicants (see Fig. 3).

Similarly, the biomass from the culture without $\mathrm{CN}^{-}$appeared physically distinct from that exposed to $\mathrm{CN}^{-}$. The solute well is bigger with more gums which improves nutrient uptake in biofilms with $\mathrm{CN}^{-}$as the biomass adjusted to the inhibitory effect of the $\mathrm{CN}^{-}$and heavy metals.
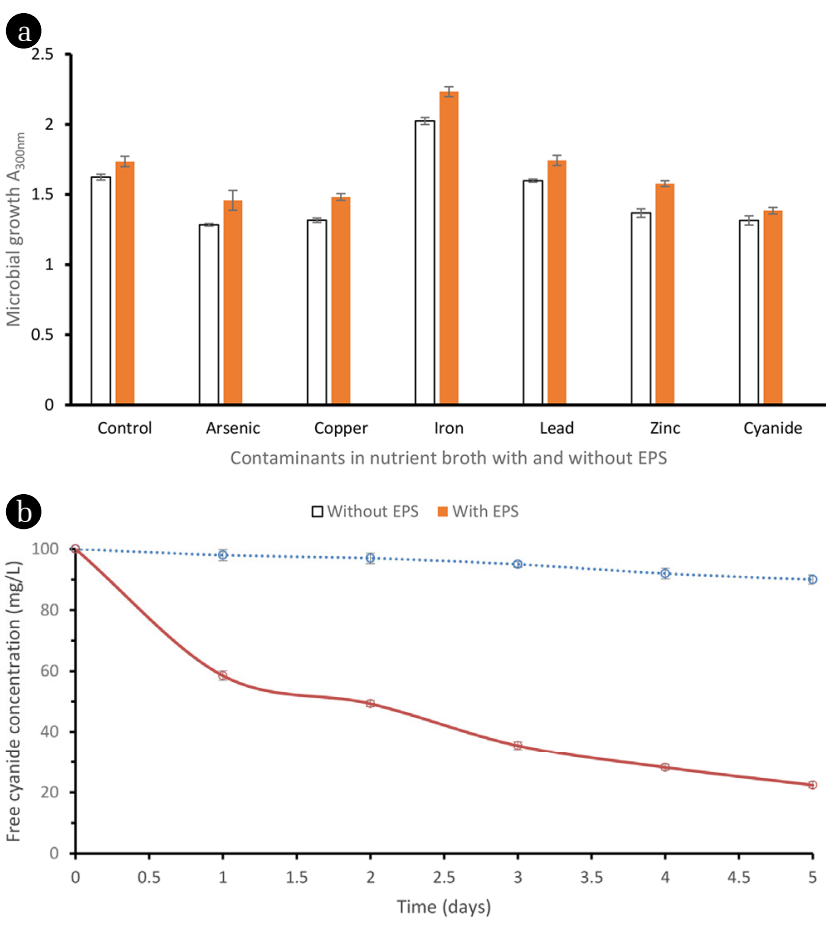

......... Control $\longrightarrow \mathrm{F}-\mathrm{CN}$

Fig. 2. (a) Isolate growth in heavy metals and free cyanide and (b) free cyanide degradation profile of the isolate.

Generally, microorganisms have different tolerance levels for heavy metals. Previous studies have indicated Fusarium sp. can tolerate most of these heavy metals up to $1,000 \mathrm{mg} / \mathrm{L}$ [21-23]. The concentration of the contaminants used in this study was higher compared with the report of Acheampong et al. [15], thus this isolate could be explored to bioremediate cyanide containing gold mine wastewater. Also, previous biochemical analysis of the isolate showed that it was dominated by aminopeptidase an indication of its suitability to survive nitrogen limitation conditions $[12,24]$. For instance, Leucine arylamidase, a type of aminopeptidase produced by this fungus isolate is a cellular enzyme that is common in bacteria and yeast, which helps to liberate amino acids from high molecular compounds [25, 26]. In addition, most heavy metal tolerant microorganisms have been shown to express these enzymes in their quest for survival in polluted environments [21, 27]. The aminopeptidases produced by this isolate was an indicator of a wide range of substrate utilisation capabilities. Previously, Anuradha et al. (2010) have established the ability of Fusarium sp. to utilise numerous carbohydrates for multi-enzyme production which was validated by other researchers [28-30].

There are limited reports on fungal biofilms besides that of Zygomycetes sp. [31], Aspergillus sp. [32, 33] and Fusarium sp. $[2,6,34]$ which indicated that inhibitors such as $\mathrm{CN}^{-}, \mathrm{SCN}^{-}$and fungicides have adverse effect on the architecture of the Fusarium sp. The bigger solute wells within the biofilms of the isolate suggested minimal impact of the $\mathrm{CN}^{-}$on the structural characteristics of the biofilm formed by the $F$. oxysporum isolate. The presence of $\mathrm{CN}^{-}$within the biomass walls is a key factor in cellular respiration. 

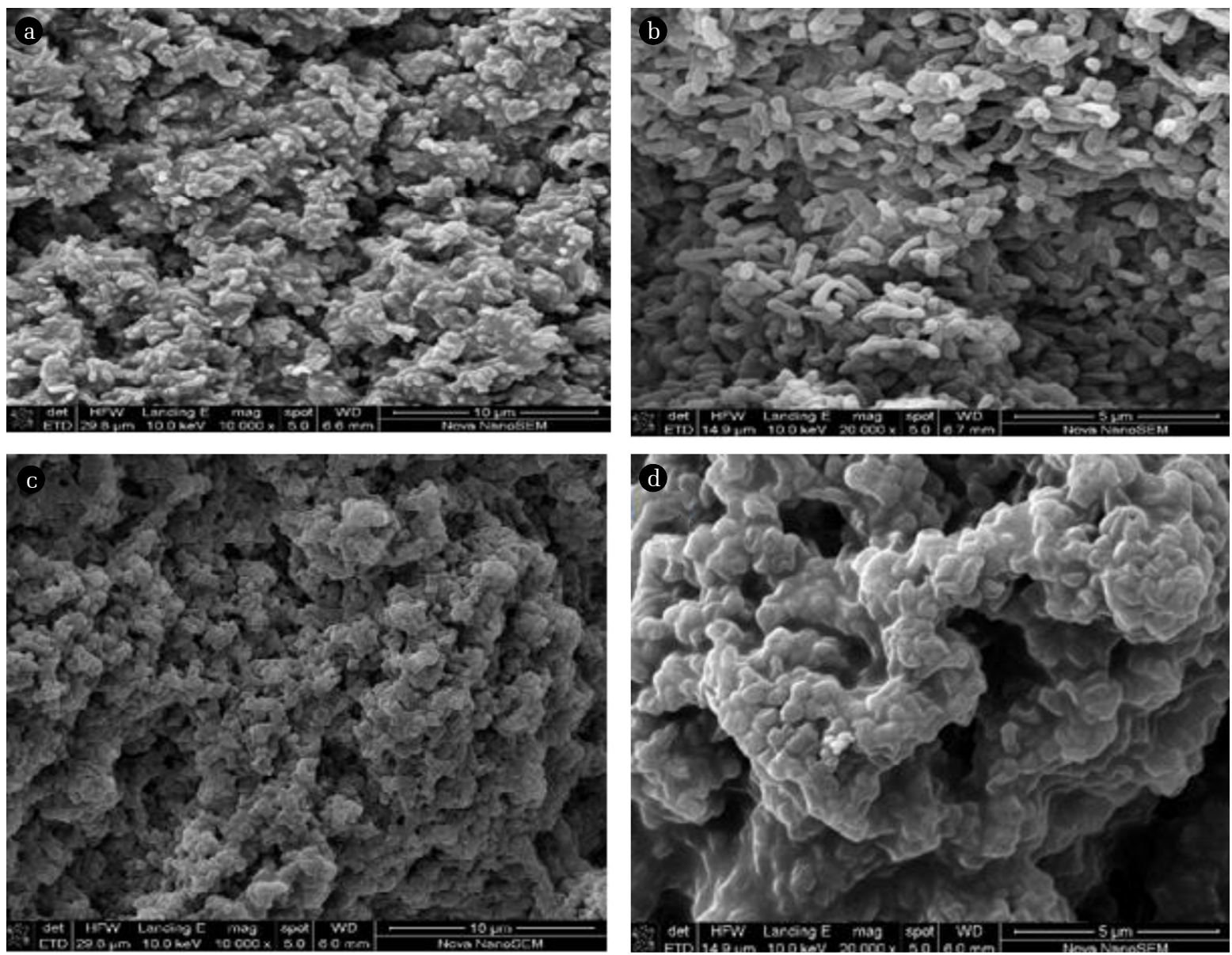

Fig. 3. Scanning electron micrographs of Fusarium oxysporum biofilm from cultures without cyanide (a-b) and those with cyanide (c-d).

\section{Conclusions}

This study showed the ability of $F$. oxysporum EKT01/02, which was isolated from the rhizosphere of $Z$. mays contaminated with cyanide-based pesticide, and was able to degrade free cyanide with $77.6 \%$ degradation efficiency after $5 \mathrm{~d}$. The isolate was able to grow in the presence of both cyanide and heavy metals which makes it a suitable candidate for biological treatment of wastewater on a large scale. Inaddition, the growth of the isolate was aided by the production of EPS, an information that is invaluable for the design of microbial wastewater treatment plant. However, it is recommended that studies on simultaneous biodegradation of metal-complex cyanide and free cyanide, including genes and degradation enzymes involved be investigated for a holistic environmental engineering applications.

\section{Acknowledgments}

The authors acknowledge the funding from the Cape Peninsula University of Technology (CPUT), University Research Fund (URF RK 16).

\section{References}

1. Maniyam MN, Sjahrir F, Ibrahim AL. Bioremediation of cyanide by optimized resting cells of Rhodococcus strains isolated from Peninsular Malaysia. Int. J. Biosci. Biochem. Bioinform. 2011;1:98-102.

2. Mukherjee PK, Chandra J, Yu C, Sun Y, Pearlman E, Ghannoum MA. Characterization of Fusarium keratitis outbreak isolates: Contribution of biofilms to antimicrobial resistance and pathogenesis. Invest. Ophthalmol. Vis. Sci. 2012;53:4450-4457.

3. Dash RR, Gaur A, Balomajumder C. Cyanide in industrial wastewaters and its removal: A review on biotreatment. J. Hazard. Mater. 2009;163:1-11.

4. Hubbe MA, Hasan SH, Ducoste JJ. Cellulosic substrates for removal of pollutants from aqueous systems: A review. 1. Metals. BioResources 2011;6:2161-2287.

5. Du Plessis C, Barnard P, Muhlbauer R, Naldrett K. Empirical model for the autotrophic biodegradation of thiocyanate in an activated sludge reactor. Lett. Appl. Microbiol. 2001;32:103-107.

6. Huddy RJ, van Zyl AW, van Hille RP, Harrison STL Characterisation of the complex microbial community asso- 
ciated with the ASTERTM thiocyanate biodegradation system. Miner. Eng. 2015;76:65-71.

7. Barclay M, Tett VA, Knowles CJ. Metabolism and enzymology of cyanide/metallocyanide biodegradation by Fusarium solani under neutral and acidic conditions. Enzym. Microb. Technol. 1998;23:321-330.

8. Santos BAQ, Ntwampe SKO, Hamuel J, Muchatibaya G. Application of Citrus sinensis solid waste as a pseudo-catalyst for free cyanide conversion under alkaline conditions. BioResources 2013;8:3461-3467.

9. Khamar Z, Makhdoumi-Kakhki A, Mahmudy Gharaie MH. Remediation of cyanide from the gold mine tailing pond by a novel bacterial co-culture. Int. Biodeter. Biodegr. 2015;99:123-128.

10. Mekuto L, Alegbeleye OO, Ntwampe SKO, Ngongang MM, Mudumbi JB, Akinpelu EA. Co-metabolism of thiocyanate and free cyanide by Exiguobacterium acetylicum and Bacillus marisflavi under alkaline conditions. 3 Biotech 2016;6:1-11.

11. Leslie JF, Summerell BA, Bullock S. The Fusarium laboratory manual. Wiley Online Library; 2006.

12. Akinpelu EA, Adetunji AT, Ntwampe SKO, Nchu F, Mekuto L. Biochemical characteristics of a free cyanide and total nitrogen assimilating Fusarium oxysporum EKT01/02 isolate from cyanide contaminated soil. Data Brief 2017;14:84-87.

13. Tamura K, Stecher G, Peterson D, Filipski A, Kumar S. MEGA6: Molecular evolutionary genetics analysis version 6.0. Mol. Biol. Evol. 2013;30:2725-2729.

14. Kimura M. A simple method for estimating evolutionary rates of base substitutions through comparative studies of nucleotide sequences. J. Mol. Evol. 1980;16:111-120.

15. Acheampong MA, Paksirajan K, Lens PNL. Assessment of the effluent quality from a gold mining industry in Ghana. Environ. Sci. Pollut. Res. 2013;20:3799-3811.

16. O’Donnell K, Kistler HC, Cigelnik E, Ploetz RC. Multiple evolutionary origins of the fungus causing Panama disease of banana: Concordant evidence from nuclear and mitochondrial gene genealogies. Proc. Natl. Acad. Sci. USA 1998;95:2044-2049.

17. Bogale M, Wingfield BD, Wingfield MJ, Steenkamp ET. Characterization of Fusarium oxysporum isolates from Ethiopia using AFLP, SSR and DNA sequence analyses. Fungal Divers. 2006;23:51-66.

18. Kruger MC, Bertin PN, Heipieper HJ, Arsène-Ploetze F. Bacterial metabolism of environmental arsenic - Mechanisms and biotechnological applications. Appl. Microbiol. Biotechnol. 2013;97: 3827-3841.

19. Akcil A. Destruction of cyanide in gold mill effluents: Biological versus chemical treatments. Biotechnol Adv. 2003;21:501-511.

20. Ebbs S. Biological degradation of cyanide compounds. Curr. Opin. Biotechnol. 2004;15:231-236.
21. Durve A, Naphade S, Bhot M, Varghese J, Chandra N. Characterisation of metal and xenobiotic resistance in bacteria isolated from textile effluent. Adv. Appl. Sci. Res. 2012;3: 2801-2806.

22. Jha S, Chauhan R, Dikshit S. Fungal biomass as biosorbent for removal of heavy metal from industrial wastewater effluent. Asian J. Plant Sci. 2014;13:93.

23. Verma P, Singh S, Verma R. Heavy metal biosorption by Fusarium strains isolated from iron ore mines overburden soil Int. J. Environ. Sci. Toxicol. Res. 2016;4:61-69.

24. Sala M, Karner M, Arin L, Marrasé C. Measurement of ectoenzyme activities as an indication of inorganic nutrient imbalance in microbial communities. Aquat. Microb. Ecol. 2001;23:301-311.

25. Müller T, Müller M, Behrendt U. Leucine arylamidase activity in the phyllosphere and the litter layer of a Scots pine forest. FEMS Microbiol. Ecol. 2004;47:153-159.

26. Chróst RJ. Significance of bacterial ectoenzymes in aquatic environments. In: Ilmavirta V, Jones RI, eds. The dynamics and use of lacustrine ecosystems: Proceedings of the 40-Year Jubilee Symposium of the Finnish Limnological Society, held in Helsinki, Finland, 6-10 August 1990. Dordrecht: Springer Netherlands; 1992. p. 61-70.

27. Gadd GM. Metals, minerals and microbes: Geomicrobiology and bioremediation. Microbiology 2010;156:609-643.

28. Akinpelu EA, Amodu OS, Mpongwana N, Ntwampe SKO, Ojumu TV. Utilization of Beta vulgaris agrowaste in biodegradation of cyanide contaminated wastewater. In: Ekinci D, ed. Biotechnology. Croatia: INTECH; 2015. p. 59-75.

29. Paper JM, Scott-Craig JS, Cavalier D, et al. $\alpha$-Fucosidases with different substrate specificities from two species of Fusarium. Appl. Microbiol. Biotechnol. 2013;97:5371-5380.

30. Anuradha K, Padma PN, Venkateshwar S, Reddy G. Fungal isolates from natural pectic substrates for polygalacturonase and multienzyme production. Indian J. Microbiol. 2010;50:339-344.

31. Singh R, Shivaprakash M, Chakrabarti A. Biofilm formation by zygomycetes: Quantification, structure and matrix composition. Microbiology 2011;157:2611-2618.

32. Seidler MJ, Salvenmoser S, Müller F-MC. Aspergillus fumigatus forms biofilms with reduced antifungal drug susceptibility on bronchial epithelial cells. Antimicrob. Agents Chemother. 2008;52:4130-4136.

33. Mowat E, Williams C, Jones B, Mcchlery S, Ramage G. The characteristics of Aspergillus fumigatus mycetoma development: Is this a biofilm? Med. Mycol. 2009;47:S120-126.

34. Peiqian L, Xiaoming P, Huifang S, Jingxin Z, Ning H, Birun L. Biofilm formation by Fusarium oxysporum f. sp. cucumerinum and susceptibility to environmental stress. FEMS Microbiol. Lett. 2014;350:138-145. 